\title{
GIS Applied to Integrated Coastal Zone and Ocean Management: Mapping, Change Detection and Spatial Modeling for Coastal Management in Southern Brazil
}

\author{
Tatiana S. da Silva, Maria Luiza Rosa and Flávia Farina
}

Additional information is available at the end of the chapter

http://dx.doi.org/10.5772/47840

\section{Introduction}

Information is the basis for sustainable development. If a decision is taken without any quality information to back it up, it relies on guesswork. Accurate, comprehensive and periodic environmental information is then crucial for the success of the decision-making and environmental planning processes.

Coastal zones are characterized by fragile, complex and productive environments, typical of the sea-land system. They deserve special attention from the government and society. Besides, most of the world population lives by the sea and there is a permanent trend of demographic concentration in these areas. The health and well-being of the coastal populations, and sometimes even their survival, depend on the status of coastal and marine ecosystems. Managing this complexity implies the cooperation between the levels of the government and the society.

In Brazil, the National Coastal Management Plan (PNGC) was established through the Law 7661 of 1988 in order to plan the use of coastal areas. Today in its second version, the PNGC provides the following instruments: (1) the State Coastal Management Plan (PEGC), clarifies the development of the PNGC at the state level, aiming to implement a State Coastal Management Policy; (2) the Municipal Coastal Management Plan (PMGC), clarifies the development of the PNGC and PEGC at the municipal level, aiming to implement a Municipal Coastal Management Policy; (3) the Coastal Management Information System (SIGERCO) is a component of the National Environmental Information System (SINIMA) and gives support to the state / municipal subsystems; (4) the Environmental Monitoring 
System (SMA-ZC) is the operational framework of continuous data collection to monitor the social-environmental indicators and support the management plans in the coastal zone; (5) the Environmental Quality Report (RQA-ZC) is the consolidation of results from the SMA$\mathrm{ZC}$ in periodic reports and, above all, aims to assess the efficiency of the management actions undertaken; (6) the Ecologic-Economic Coastal Zoning (ZEEC) is the spatial regulatory instrument to plan land use in a given territory; and (7) the Coastal Zone Management Plan (PGZC) is a set of coordinated and programmatic actions, built in a participatory manner, and applicable to different levels of government.

Unfortunately, more than 20 years after the implementation of the 7661 Law, the institutionalization of coastal management is still incipient (Jablonski and Filet, 2008), even in the Rio Grande do Sul State, where the environmental control is very restrictive compared to the rest of the country. In some municipalities of the Rio Grande do Sul coastal plain, environmental plans were built and consist in the only environmental regulatory instruments at municipal level, but they are not truly implemented. At the national level, on the other hand, the adoption of the I3Geo as component of SINIMA was a successful initiative. The I3Geo is a platform for publishing spatial data and interactive mapping applications to the web, helping the establishment of cooperative networks, showing the advantages of using a GIS platform as the core of an environmental information system.

In a general sense, all the coastal management instruments, as they are designed in the PNGC, explicitly depend on spatial tools or at least would be benefited through the use of maps. The universities focused on the coastal and marine ecosystems of the Rio Grande do Sul generate a number of GIS-based products as research results. They have been helpful in building the environmental and master plans of many coastal municipalities, but there is still a great potential to include spatial information in other mechanisms of coastal management. A significant knowledge about the natural resources in this region has been gained from GIS and remote sensing in the last 30 years. Geotechnology has been successfully used to understand the spatial structure and dynamics of the coastal landscapes and, more recently, in simulation modeling and change prediction. The acquired knowledge should be included into the existing instruments, and also used to improve them, promoting the adaptation to the current pace and reach of human activities over the coastal zone.

The Rio Grande do Sul coastal zone (figure 1), in Southern Brazil, is characterized by a wide coastal plain generated by the sea level changes during the Quaternary, which resulted in a complex lagoon system all over its extent (Asmus et al., 1988). The Patos Lagoon is the most expressive of such water bodies, comprising almost $10.000 \mathrm{~km}^{2}$ and a number of valuable marginal ecosystems and aquatic species, some of them of economic interest. Research has been focused on coastal issues for more than 20 years. And since then, space has been the base of approach.

Thus, this chapter aims to provide a discussion about the applicability of the mapping, change detection and spatial modeling efforts in the Southern Brazil coastal plain to the policy instruments defined by the National Coastal Management Plan. We also recommend strategies to promote an adaptative management concerning coastal zones through the use 
of GIS. Geotechnology will be presented as a way to enhance the exchange and feedback among academic researchers, stakeholders and community.

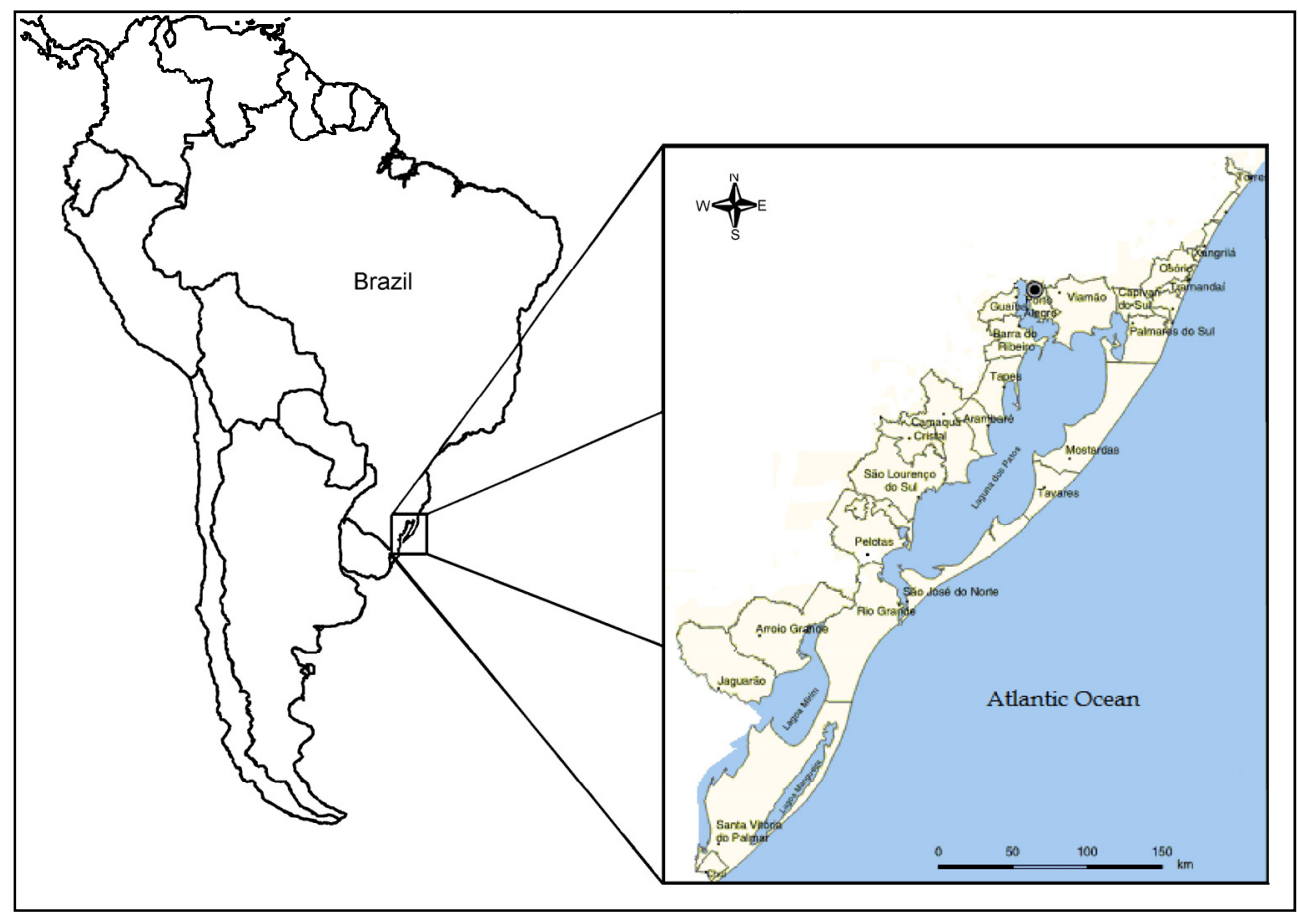

Figure 1. Rio Grande do Sul coastal zone.

\section{The Brazilian program on coastal management: Implementation status and spatial nature of policy instruments}

The second National Plan of Coastal Management - PNGC II was approved in 1997, in substitution of PNGC I. The National Program on Coastal and Ocean Management (GERCOM) aims to put PNGC into operation, in order to plan and manage the economic activities so to ensure the sustainable use of the coastal environments. GERCO is coordinated by the Ministry of Environment and executed by the 17 coastal states. Rio Grande do Sul is one of the most advanced states regarding the implementation of the coastal management plan, but actions are highly concentrated in the north littoral where urbanization is more spread and severe.

The State Envionmental Protection Agency (FEPAM) is the state-level authority in charge of environmental management in Rio Grande do Sul. FEPAM is legally in charge of implementing the Coastal Management Program. The participation of FEPAM, as the ultimate client for the management plans, is crucial to guarantee long-term sustainability of applied research endeavors. To the extent that FEPAM takes ownership of projects results, 
and makes the proposed plans its own, this would guarantee that such plans are incorporated in the State's budged and overall environmental policy (Tagliani et al., 2003).

The Rio Grande do Sul coastal zone comprises 27 coastal municipalities: Torres, Arroio do Sal, Três Cachoeiras, Três Forquilhas, Maquiné, Capão da Canoa, Terra da Areia, Xangrilá, Osório, Imbé, Tramandaí, Cidreira, Palmares do Sul, Viamão, Mostardas, Barra do Ribeiro, Tapes, Tavares, Camaquã, Arambé, São José do Norte, São Lourenço do Sul, Rio Grande, Pelotas, Arroio Grande, Jaguarão, and Santa Vitória do Palmar. Only 9 of them have environmental plans approved by FEPAM. However, conservation units and preservation areas are considered in most of the master plans. In some municipalities, they are the only instrument of environmental and territorial control.

The State Plan of Coastal Management (PEGC) and the Municipal Plan of Coastal Management (PMGC) are highly related to territorial ordination planning. Environmental zoning proposals as well as the detection of priority areas for management subside state and municipal plans. This is particularly important for those municipalities where the lack of human and technological resources is more dramatic.

Environmental zoning proposals can also base the Coastal Ecological-Economic Zoning (ZEEC), which aims to regulate the territorial use in order to achieve environmental sustainability of the coastal zone development, respecting the directives of the EcologicalEconomic Zoning in national scale.

GIS-based project results in general are potential inputs for the Coastal Management Information System (SIGERCO), a component of the National System of Environmental Information (SINIMA). SIGERCO integrates PNGC information, aiming to give support and capillarity to the subsystems structured and managed by coastal states and municipalities.

Research results that also include a temporal dimension (land use change studies, for example) give GIS procedures the status of a monitoring method, once they can be replicated in other times or locations. This type of spatial data can be used as environmental quality indicators and, thus, can be incorporated by the Coastal Zone Environmental Monitoring System (SMA-ZC). Consequently, they are able to support the Coastal Zone Environmental Quality Report (RQA-ZC), which is the periodic consolidation of the results obtained by the environmental monitoring.

Once the institutions involved in public management have absorbed the available technology and information, the possibilities of use them in the decision making process are diverse. The possibility to visualize any attribute in a map makes easier to understand the coastal space, promoting knowledge-based public participation in the decision making process. The chance of governance to succeed is higher in this way.

In a general sense, all the coastal management instruments, as they are designed in the PNGC, explicitly depend on spatial tools or at least would be benefited through the use of maps. Some of the GIS-based research works have already been helpful in building the environmental and master plans of some coastal municipalities (Pelotas, Rio Grande, São Lourenço do Sul, Turuçu, among others) but there is still a great potential to include this 
information in other mechanisms of coastal management. Geotechnology has been successfully used to understand the spatial structure and dynamics of medium littoral of the Rio Grande do Sul coastal plain. The acquired knowledge should also be included into the existing instruments to improve them, providing a more prospective focus and promoting the adaptation to the current pace and reach of human activities over the coastal zone.

\section{Rio Grande do Sul coastal plain: Mapping, change detection and spatial modeling as decision support resources}

\subsection{Mapping the coastal zone}

PNGC delegates power for states and municipalities to legislate issues related to the use of soil, water and forest resources. Based on that, municipalities are highly recommended to create master plans and legal instruments to manage land use, mantain environmental quality, and use properly the natural resources at municipal level. Several methods are involved in the implementation of a master plan, like statistical analysis, mapping, zoning, registration survey, field research, among others. Thus, GIS represents an extremely useful tool for municipal planning purposes. GIS gathers together a great set of application to collect, storage, restore, change, and represent spatial data, as well as related attributes. GIS implementation, as the basis for planning and management, means a huge step toward a greater efficiency of municipal administration.

Basic GIS questions, such as when, what, what distance, and which, sometimes need integrating tools to be answered. In this sense, Multi Criteria Evaluation (MCE) techniques are effective procedures for several purposes. Gómez \& Barredo (2005) have analyzed GIS analytical functions integrated to MCE techniques, which allows introducing objective and/or heuristic knowledge to simulate the possible results of different decisions and develop virtual scenarios to evaluate the implementation of policies.

\subsubsection{Geological and geomorphologic mapping of coastal plain as the basis for land use planning}

The knowledge about the substrate and geological evolution is a very important point for planning the use of coastal environments. When considering the substrate characteristics, we might evaluate the best way and location for development, integrating human interests with the particularities of each environment.

Rio Grande do Sul coastal plain geology has been studied over the years especially through surface geological mapping, supported by remote sensing data, drilling, and more recently, geophysical surveys. This information can be integrated and made available through GIS, allowing its use in several applications.

Rio Grande do Sul coastal plain represents the top and youngest portion of the Pelotas sedimentary basin. It is mainly formed by alluvial fan and barrier-lagoon sedimentary deposits (figure 2). According to previous works, these deposits were formed in response to 
sea level changes, which were controlled by glacioeustasy during the Quaternary. Mineralogical and geomorphological patterns result in four barrier-lagoon systems. The oldest system is designated as I and the youngest (still active) as IV (Tomazelli \& Villwock, 1996). The age of the oldest systems was established mainly by correlation with oxygen isotope curves. Each system represents the maximum of the Postglacial Marine Transgression (PMT): $400 \mathrm{ka}$ (I), $325 \mathrm{ka}$ (II) and $120 \mathrm{ka}$ (III).

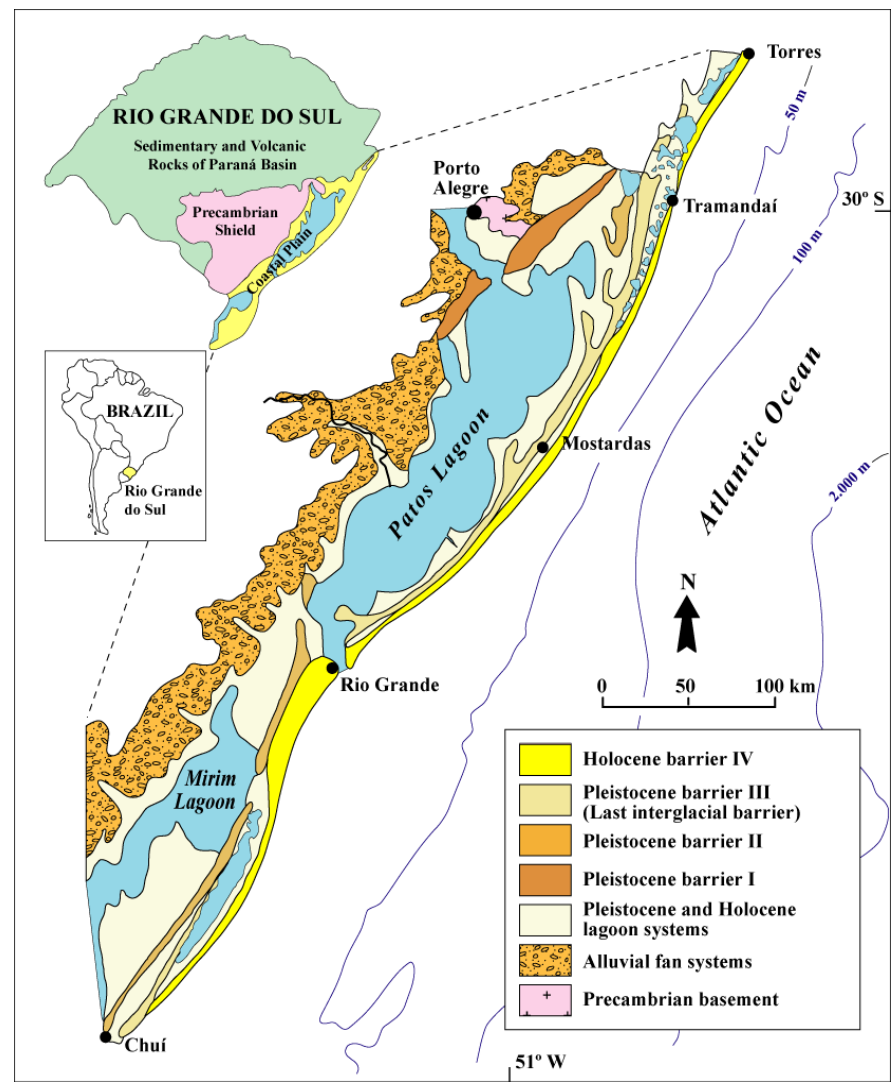

Figure 2. Map of Rio Grande do Sul coastal plain, showing its main geological units (Tomazelli \& Villwock, 1996).

The youngest system (IV) is a record of the last glacial cycle, which evolved after the last glacial maximum about $18 \mathrm{ka}$ ago. This is the best kwon geological unit of the Rio Grande do Sul coastal plain, where most of the coastal population lives. Sea level was placed around 120-130 m below the current level about $18 \mathrm{ka}$ ago (Corrêa, 1995). Thereafter, sea level started to rise, exceeding the current level at 7.7-6.9 ka, and reaching its maximum at about 6 ka (Martin et al., 1979; Angulo \& Lessa, 1997). By this time, it reached a high 2 to $4 \mathrm{~m}$ above the present sea level (Dillenburg et al., 2000). Since then, it has begun lowering to the current position (Angulo \& Lessa, 1997). 
Sea level changes controlled the evolution of depositional systems found in the Rio Grande do Sul coastal plain. The deposits associated to this cycle reflect such variations. The understanding of elements composing coastal environments and how they evolved over the last thousands years may be applied to several purposes.

Dillenburg et al. (2000) have studied the Holocenic coastal barrier, defining sectors with divergent behaviors in a scale of centuries to millennia. Some sectors are under erosion, others are stable or quasi-stable, and we also find sectors where the beach is growing. Toldo Jr. et al. (2005) showed that $442 \mathrm{~km}$ of $621 \mathrm{~km}$ of coastline have been eroded. One of the main indicators of this process is the mud outcrop of lagoonal origin in the present beach (figure 3). ${ }^{14} \mathrm{C}$ dating procedures revealed the age of these muds: $5760 \pm 120 \mathrm{ka}$ according to Travessas (2003), 4,330 $\pm 60 \mathrm{ka}$ according to Tomazelli et al. (1998), and $3.5 \mathrm{ka}$ according to Dillenburg et al. (2004), indicating that the coastal barrier is regressing in these sectors.

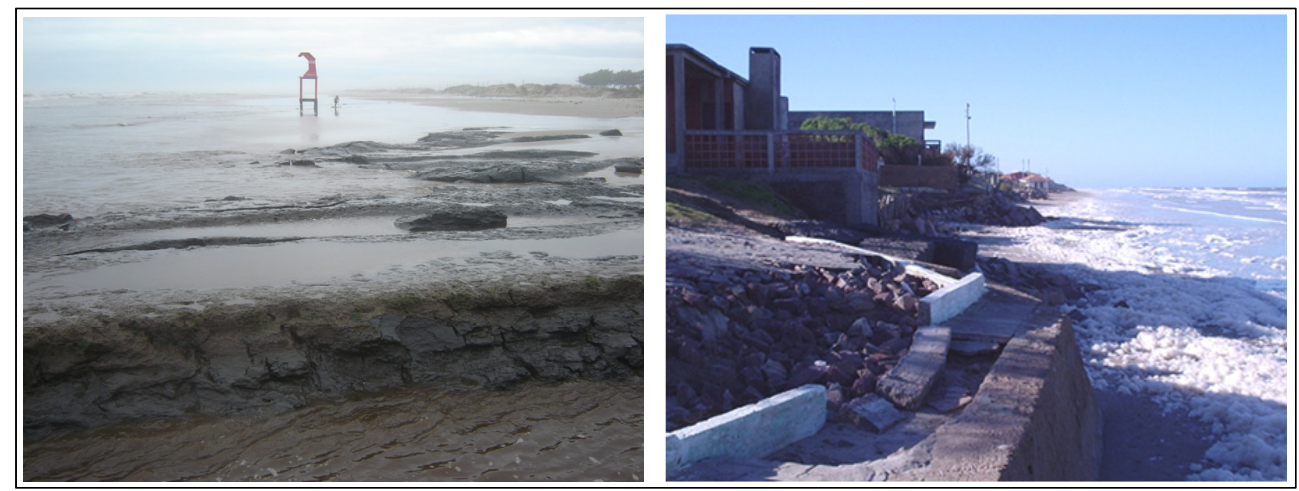

Figure 3. Pictures showing beach erosion indicators. The left picture shows mud outcropping at the beach and the right one the buildings destruction due to sea level rises during storms.

GIS-based analysis of outcrops along with satellite images allowed to clarify some specific characteristics of these sectors. Given their particular locations along the coast, they are frequently associated to the occurrence of great dune fields (figure 4). Dune fields are generally found in the far northeastern of the sectors under erosion, what is related to longshore drift (Tomazelli \& Villwock, 1992; Toldo Jr. et al., 2004).

The human occupation of some sectors under erosion already has negative consequences. When an elevation of sea level occurs, as a result of meteorological tides, we face the destruction of residences and infrastruture (figure 3). Sectors under erosion should be treated differently from those under accretion in the planning process. It is absolutely necessary to concern about safety measures, such as the maintenance of buffer zones free of development near the beach.

After the expansion of the coastal zone occupation, energy resources are increasingly required. An alternative adopted along Brazilian southern coast is the installation of wind generators. For determining the better place to install them, we must consider several criteria, including legal and socio-environmental aspects. 


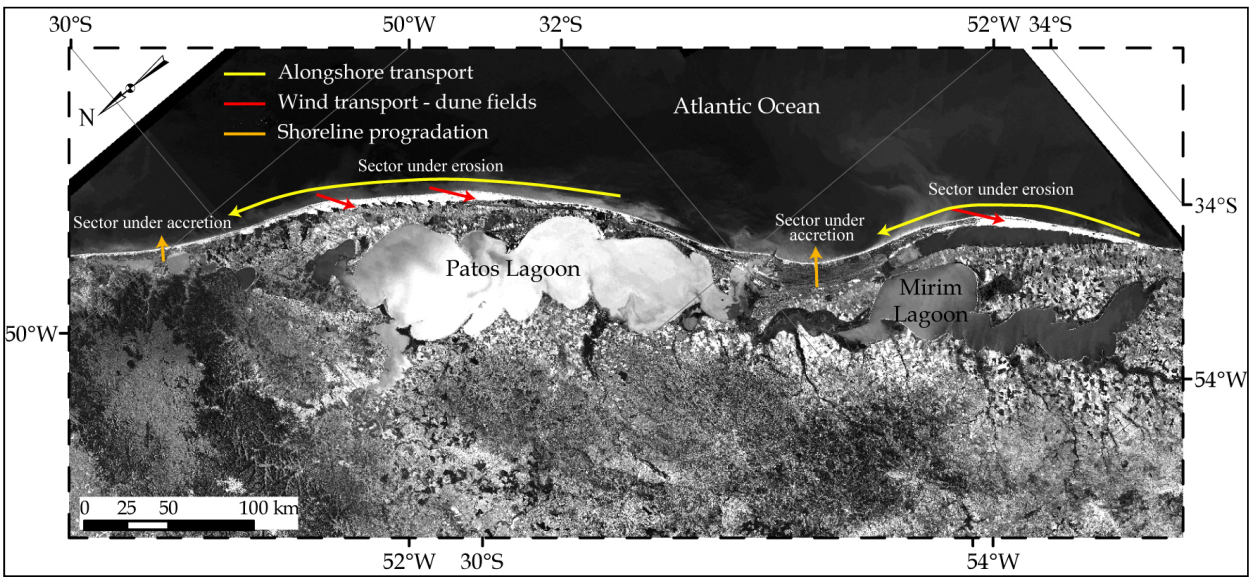

Figure 4. Image of Rio Grande do Sul coastal plain (Landsat 7, ETM+, Band 2 - $130^{\circ}$ inclination) showing its embayments and projections. Alongshore transportation is indicated. Extensive transgressive dune fields occur mainly in the NE portion of erosion sectors (Rosa, 2010).

According to the Brazilian environmental law, dunes are preservation areas. However, the understanding of dune fields dynamic allows to predict dune behavior. Many dune fields in southern Brazil have been monitored by historical aerial photography. Many of them are endangered. Cidreira dune fields are an example of that (figure 5). This field used to be maintained by a sand supply transported by NE winds. Urban development has blocked sand transportation in this area. Thus, dunes and sand sheets are about to disappear, once there is no alternative sand supply to keep sand dunes in place and the current dunes tend to migrate toward coastal lagoons, away from the beaches. The environmental agency in charge authorized a wind farm installation in this area, once sustainable dune fields no longer exist.

In a general sense, when we apply coastal dynamic knowledge to land use planning, environmental impacts of development are likely to be reduced, and a better balance between human needs and the coastal systems carrying capacity is reached.

\subsubsection{Modeling of urban sprawl based on GIS: The Rio Grande city case, south coastal plain}

The human activities planning process imply combining multiple criteria, including law, ecological function of environments, and human needs. In this sense, a GIS-based urban sprawl model was built by Farina (2003), using a multi-criteria evaluation as a tool for decision making. Rio Grande was chosen to develop a case study of urban sprawl. It has been urbanized and industrialized in an unplanned manner, resulting in environmental degradation of many valuable ecosystems. Rio Grande is located in the south littoral of the Rio Grande do Sul coastal plain (Figure 1). The urban area is physically limited by water, once it is surrounded by the Atlantic Ocean on the east and by the Patos Lagoon on the north and west. Given the physiographic characteristics of this municipality, it has a great potential to port and industrial development, which in turn drives urban expansion. 


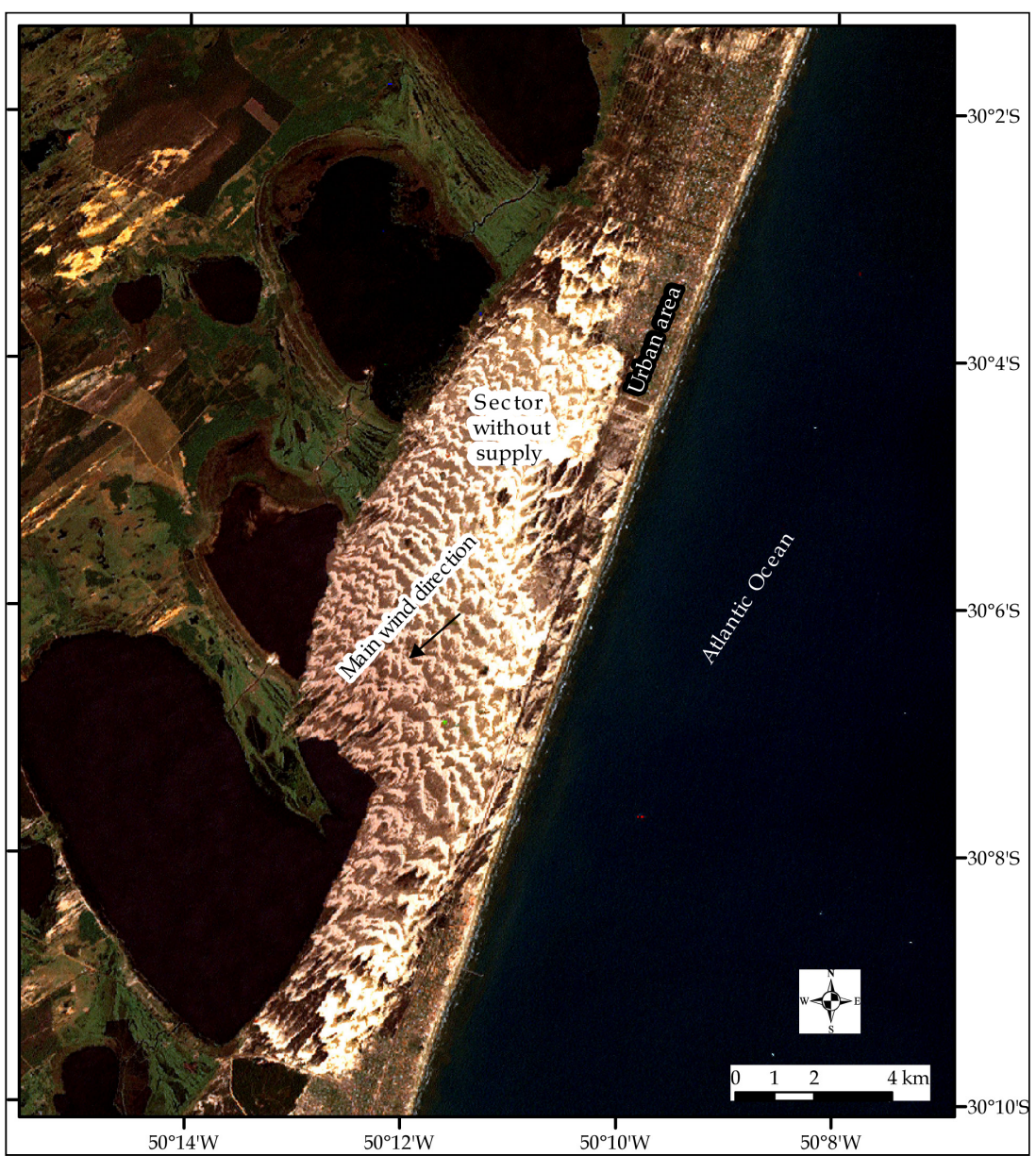

Figure 5. Image of Cidreira dune field (Landsat 7, ETM+, R3G2B1 composition, fused with panchromatic band) showing the northern area where sand supply was canceled by urban occupation.

Decision theory is concerned with the logic by which one arrives at a choice between alternatives. A criterion is some basis for a decision that can be measured and evaluated. Criteria can be of two kinds: factors and constraints, and can pertain either to attributes of the individual or to the entire data set (Eastman et al, 1995). A criterion can enhance or detract the suitability of a specific alternative for a given activity. Constraints limits the alternatives under consideration, usually expressed in the form of Boolean maps. Factors, on the other hand, are commonly measured in a continuous scale of suitability. Decision rule is the procedure by which criteria are selected and combined to arrive at a particular evaluation (Gómez \& Barredo, 2005, apud Eastman et al, 1993).

For the Rio Grande urban development model, the following criteria were adopted: proximity to existing urban areas; proximity to the road network; environmental and cultural function of 
vegetation types; occurrence of flood areas; and occurrence of areas legally constrained to urban development. The geographic data used are presented in the Table 1. Details about the satellite images classification procedures can be found in Farina (2003) and Tagliani (1997). Criteria defined based on the proximity to target areas were obtained through by distance images, where each pixel records the distance to the nearest target feature.

\begin{tabular}{|c|c|c|}
\hline Variable & Layers & Source \\
\hline $\begin{array}{l}\text { Political boundary } \\
\text { of the municipality }\end{array}$ & Study area & Rio Grande master plan \\
\hline Urban area & $\begin{array}{l}\text { Urban area consolidated; } \\
\text { distance from the urban } \\
\text { network consolidated }\end{array}$ & $\begin{array}{l}\text { RGB543 color composition of } \\
\text { Landsat7 ETM+ images }\end{array}$ \\
\hline Road network & $\begin{array}{l}\text { Main road; distance from the } \\
\text { main road }\end{array}$ & $\begin{array}{l}\text { Topographic maps, updated based } \\
\text { on RGB543 color composition of } \\
\text { Landsat7 ETM+ images }\end{array}$ \\
\hline Vegetation & Vegetal cover & $\begin{array}{l}\text { Classification of Landsat7 ETM+ } \\
\text { images (Maximum Likelihood } \\
\text { Method) }\end{array}$ \\
\hline $\begin{array}{c}\text { Area of historical } \\
\text { and ecological } \\
\text { interest }\end{array}$ & $\begin{array}{l}\text { Active dunes, steady dunes; } \\
\text { lands recently emerged; } \\
\text { swamp; archaeological sites }\end{array}$ & Rio Grande master plan \\
\hline Hydrography & $\begin{array}{l}\text { Lakes, lagoons, canals, } \\
\text { streams, coves }\end{array}$ & $\begin{array}{l}\text { Topographic maps updated based } \\
\text { on RGB543 color composition of } \\
\text { Landsat7 ETM+ images }\end{array}$ \\
\hline Legislation & $\begin{array}{l}\text { Distance from water resources; } \\
\text { vegetation protected by law; } \\
\text { master plan; areas with slope } \\
\text { above } 30 \%\end{array}$ & $\begin{array}{l}\text { Topographic maps } \\
\text { Rio Grande master plan } \\
\text { RGB543 color composition of } \\
\text { Landsat7 ETM+ images }\end{array}$ \\
\hline $\begin{array}{l}\text { Geology } \\
\text { Geomorphology }\end{array}$ & $\begin{array}{l}\text { Flooded areas; areas subject to } \\
\text { seasonal flooding; stable } \\
\text { substrate }\end{array}$ & $\begin{array}{l}\text { Geological/geomorphologic map } \\
\text { produced by Tagliani (1997) }\end{array}$ \\
\hline
\end{tabular}

Table 1. Variables and layers relevant to urban occupation.

The following criteria were defined as constraints: a) occurrence of urban areas already consolidated; b) water bodies and water courses; and c) occurrence of preservation areas. The following criteria were defined as factors: a) proximity to urban areas and road network; b) environmental and cultural function of vegetation types; c) flood risk; and d) geologic/geomorphologic suitability to urban development.

Constraints were defined by Boolean images, where areas unsuitable to urban development are coded with a 0 and those opened for considering are coded with a 1 (figure 6). Factors, on the other hand, were standardized to a common numeric range (from 0 to 255), and then combined by means of a weighted average. This procedure is known as Weighted Linear Combination (WLC) (Eastman, 1995). 
Urban suitability was considered inversely related to the distance from water courses/bodies based on a sigmoidal basis. We choose a sigmoidal function once the need for water resources conservation is greater closer to water bodies/courses, given the higher vulnerability of marginal ecosystems. Such ecosystems tend to be more attractive to irregular settlements. People without access to sanitation and water supply use nearby waterbodies for consumption and waste disposal. The initial control point (where the suitability index start to grow) correspond to $30 \mathrm{~m}$ from water bodies/courses, once this buffer consists in a preservation area, excluded from consideration by legal constraints.

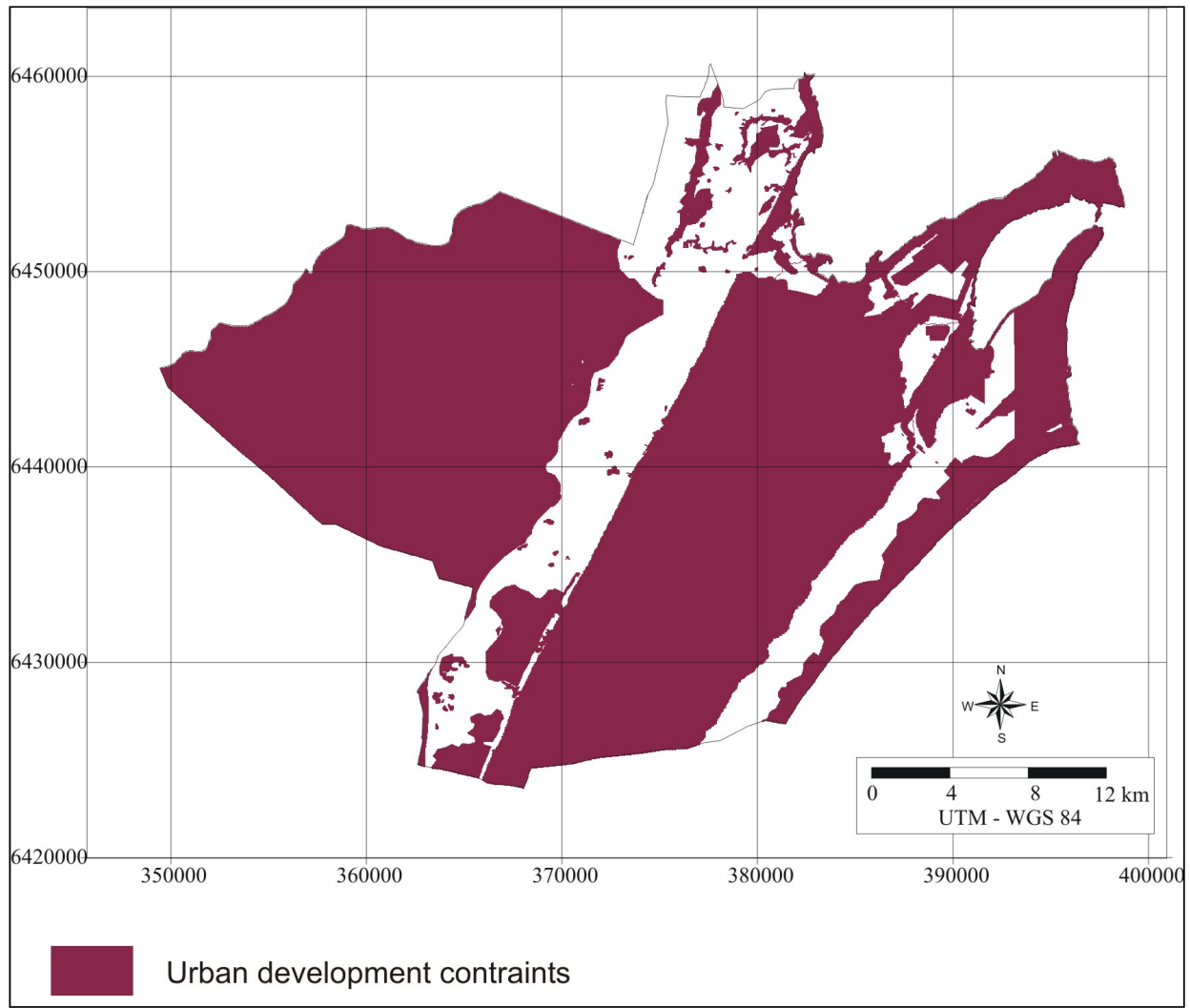

Figure 6. Areas constrained to urban development.

The proximity to the urban areas reduces infrastructure installation costs and travel time. Thus, urban suitability is related to distance from urban areas in a linear function. The same was applied regarding the proximity to road network. Control points were set at 0 and 10 $\mathrm{km}$ (figure 7).

The weight assigned to factors ranged from 1 to 5 . The final result is an image of suitability to urban development, where a value of 0 is assigned to constrained areas and a value ranging from 0 to 255 (highest suitability) is assigned to the areas under consideration, 
based on a weighted linear combination of factors. To better visualize the results, the urban suitability image was classified as follows: Class I - Very high suitability (170 -255); Classe II - High suitability (170 - 90); Class III - Medium suitability (90 - 40); and Class IV - Low suitability $(40-0)$. The urban suitability map is shown in the Figure 8.

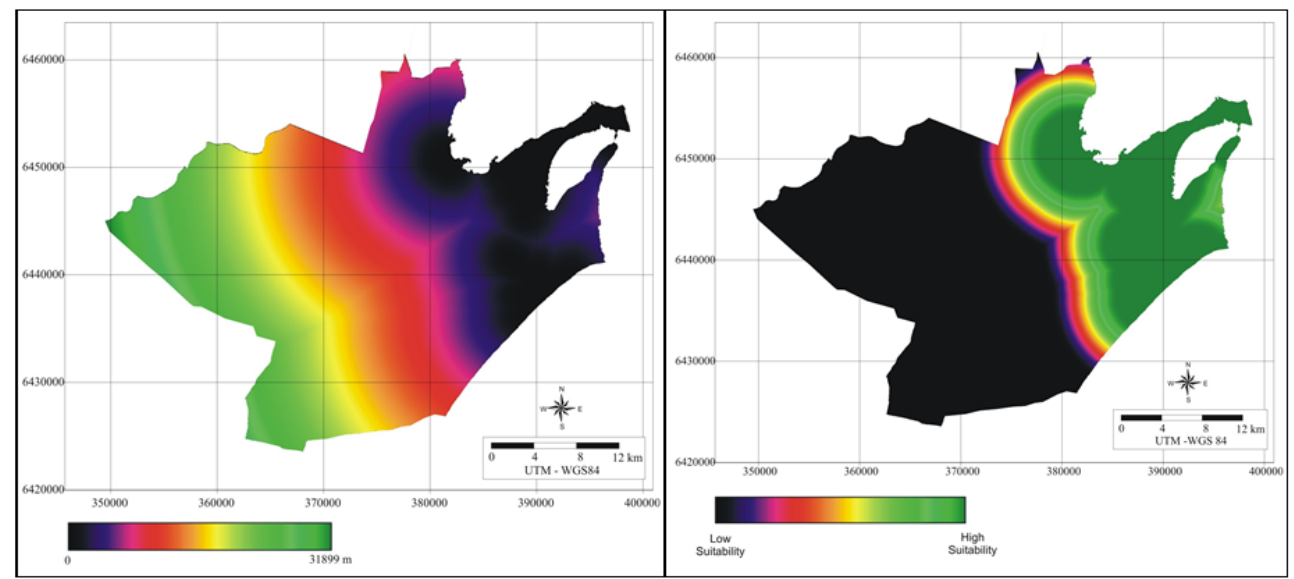

Figure 7. Distance from the urban area and suitability to urban area.

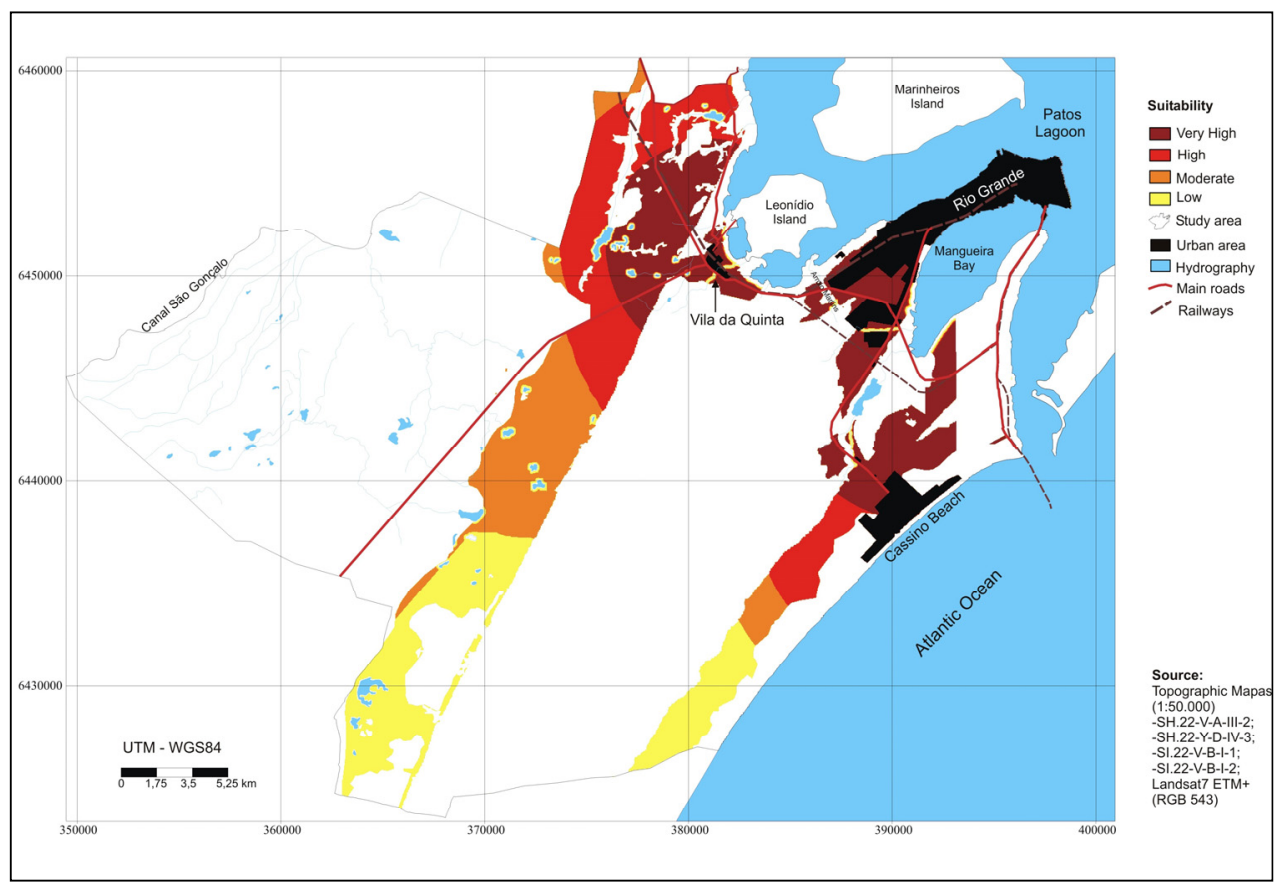

Figure 8. Suitability to urban development. 
About $723 \mathrm{~km}^{2}$ of the study area, which comprises $926 \mathrm{~km}^{2}$, consists in constrained areas to urban development. However, unconstrained areas according to the model are 5.7 times the size of the implemented urban settlements. The Classes I and II together comprise about 110 $\mathrm{km}^{2}$. Based on the model, they should be priority areas for urban development. Classes III and IV present lower suitability indexes due to the proximity to water resources. We recommend a specific occupation plan for these areas, including, for example but not limited to, public parks and reserves. Total constraints to urban development represent areas of a high ecological value. Some of them are legally protected, such as, dunes, native woods, wetlands, and aquatic ecosystems.

Spatial modeling consists in a important tool to urban development planning. However, the decision frame adopted for the Rio Grande case must be adapted to be applied in other coastal municipalities, once the relative importance of criteria can change from a place to another, as well as the environmental law at local level.

\subsection{Land use change detection and prediction in the medium littoral of the Rio Grande do Sul coastal plain}

Land use and cover changes are among the major environmental concerns of humanity today, directly or indirectly contributing to climate change, biodiversity loss, and air, soil and water pollution. They are central in the climate change scenario, once they release greenhouse gases, such as carbon compounds (due to deforestation and soil disturbance), methane (due to hydrological alterations, wetland drainage, and rice crop), and nitrogenates (due to the use of fertilizers, irrigation and burning). Besides, the natural vegetation removal by agriculture not only leaves the soil susceptible to erosion, but releases a large amount of nutrients and sediments to adjacent water bodies, causing many negative impacts on environment.

Silva \& Tagliani (2012) mapped the land use changes in the medium littoral of the Rio Grande do Sul coastal plain between 1987 and 2000 (figures 9 and 10). The land use and cover change data were used as an input in a change prediction model. Only the main anthropic changes are used in building the model, that is, changes related to deforestation, urbanization, and afforestation. These three processes synthesizes the major land use and cover changes occurred in the region. The software (GIS) interpret them, respectively, as changes from "forest" to "all" classes, from "all" classes to "urban", and from "all" classes to "silviculture".

The change prediction model results in a susceptibility to change image, varying from zero (low susceptibility) to 1 (high susceptibility).The outputs of the model along with an environmental zoning (figure 11), also proposed by Silva \& Tagliani (2012) guide decision making and environmental management toward more sustainable actions. The combination (cross tabulation) between susceptibility to change data and the environmental zoning allows to concentrate efforts in specific target areas. The environmental zoning defines the level of protection of land resources while the change prediction model points priority areas (highly susceptible to change) for each management class. Thus preservation areas highly 
susceptible to change must be the focus of conservative actions, and become priority areas to preventive management. Development areas highly susceptible to change, on the other hand, should also be the focus of actions but as priority areas to infra-structure installation or regulatory measures.

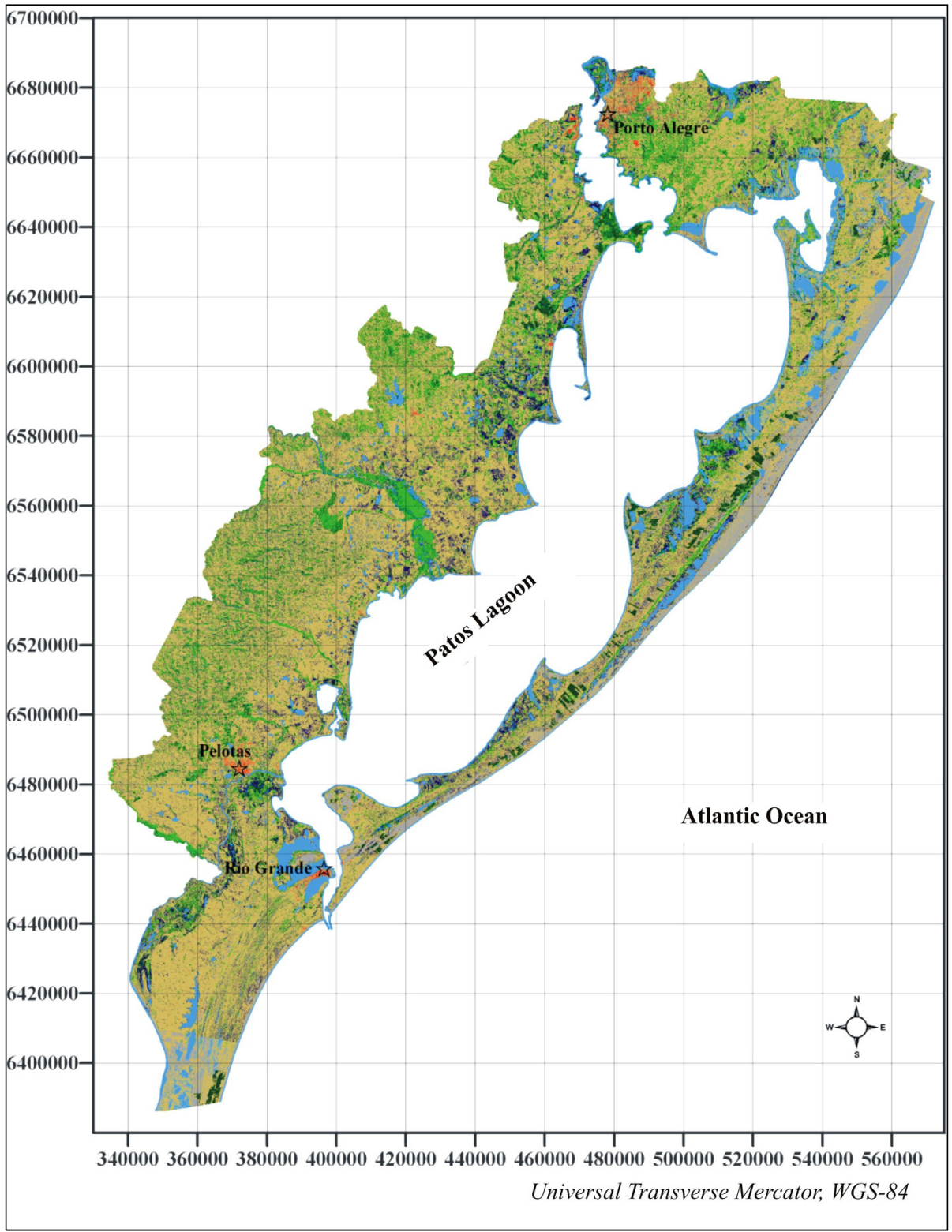

Figure 9. Land use in the medium littoral of the Rio Grande do Sul coastal plain - year 1987. 


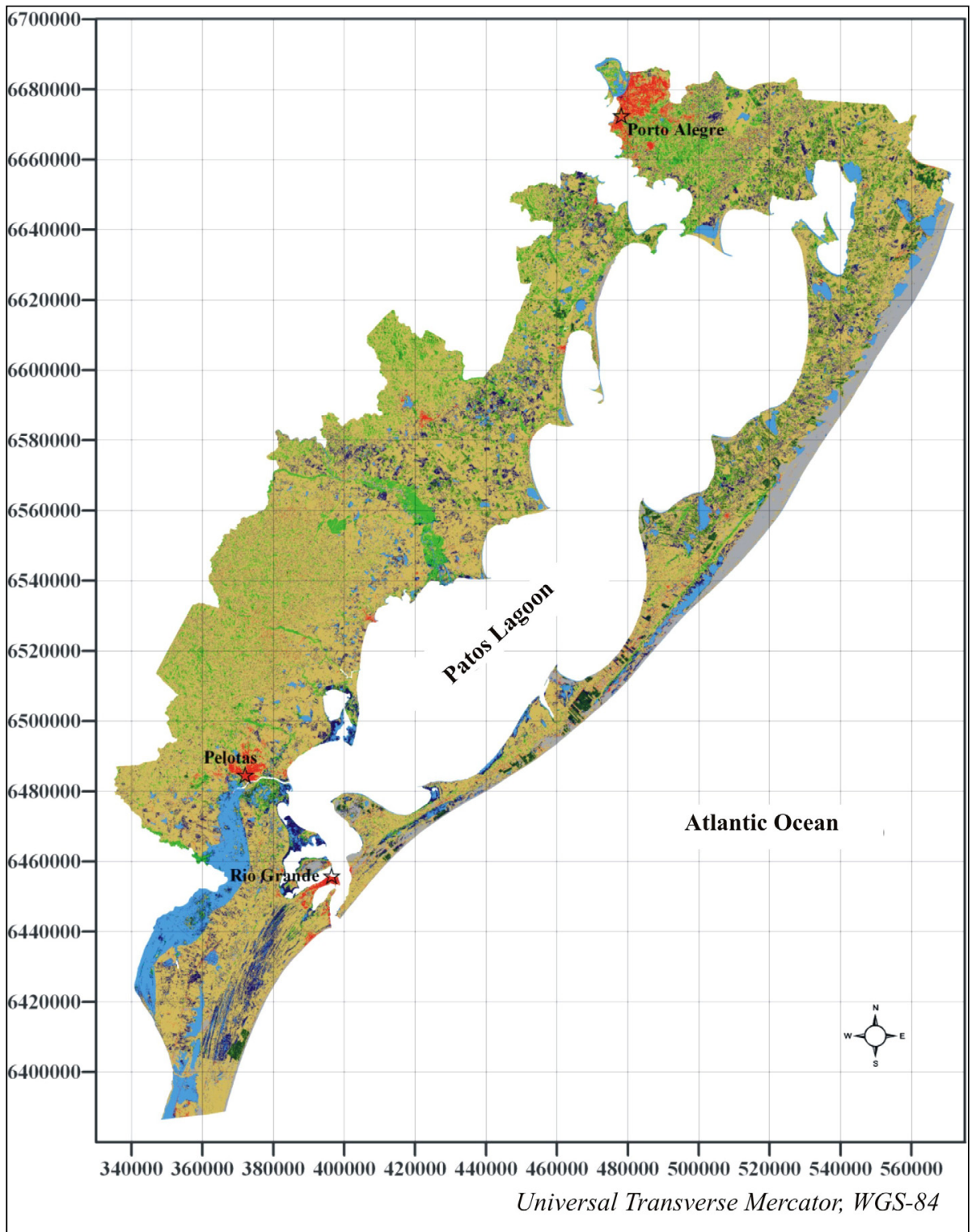

Figure 10. Land use in the medium littoral of the Rio Grande do Sul coastal plain - year 2000.

One of the impediments for the proper development and implementation of the coastal management instruments regards the selection of suitable indicators. Land use (change) seems to be an obvious choice to track several coastal processes, once it can directly or indirectly degrade the health of coastal and marine ecosystems and the services and goods they provide. Besides, it is applicable from local to global scales, acting as a binding element. 
Classical land use planning techniques can be applied to coastal zone and protected areas, based on static land use and cover maps. The environmental zoning is an example of that. Land change detection and prediction, on the other hand, can properly be used to monitor the coastal zone and base the environmental planning of these areas. In a general sense, land use based studies provide quality information for virtually all coastal management instruments in Brazil (Silva \& Tagliani, op. cit.).

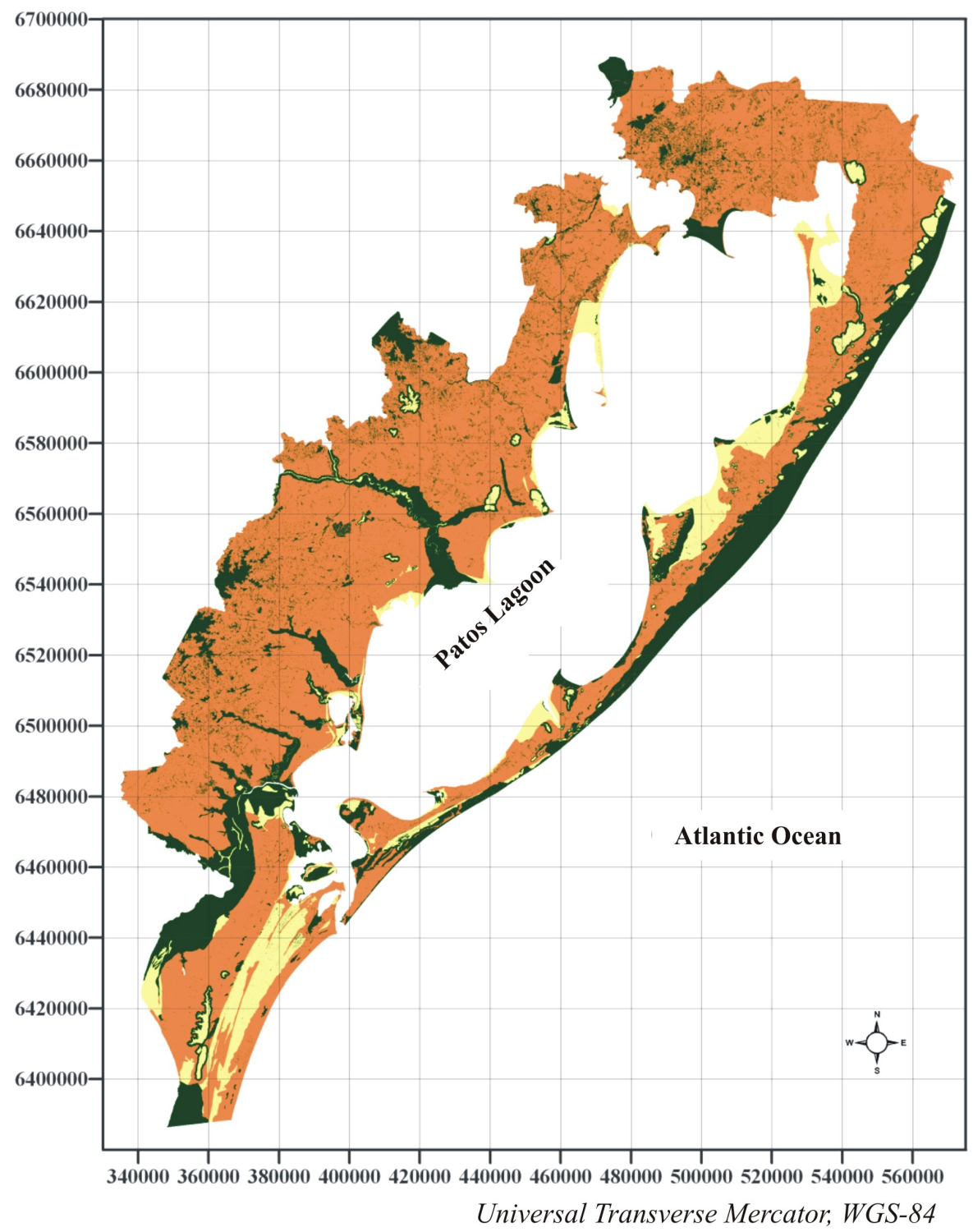

Figure 11. Environmental zoning proposal for the medium littoral of the Rio Grande do Sul coastal plain. 


\subsection{Spatial modeling subsides for risk management and coastal adaptation}

The flood and landslide control and prediction are one of our biggest challenges given the current scenario of global changes. Once the medium littoral of the Rio Grande do Sul coastal plain is increasingly urbanized and deforestated, the runoff components are altered and flood and landslide hazards worsen. In this context, GIS has excelled in the development of spatial modeling. Beyond the conventional models, GIS is capable of generating vulnerability and suitability indexes, based on map algebra and context operators, pointing areas at high-risk. Whereas Remote Sensing is an unique data source, GIS spatial modeling allows to establish multiple analytical approaches to assess local vulnerability to environmental changes.

The GIS-based models used to spatially define the relative flood and landslide risk in the medium littoral of the Rio Grande do Sul coastal plain (Silva et al., 2011) incorporates a digital elevation model and also rainfall and soil infiltration potential data to calculate flow direction and accumulation. Other criteria are derived from land use and soil data. Absolute constraints for both models comprise the occurrence of water bodies and wetlands. The resulting images shows the flood and landslide risk, in four classes: low, moderate, high, and very high. About $5 \%$ of the area had a decrease in the soil infiltration potential due to land use changes between 1987 and 2000. The flood and landslide risk models gives us a hint about what areas should be the focus of concern in the case of extreme rainfall events. It also can be used as a scenario generation tool, prospecting the effect of land use and climate changes on hydrological vulnerability. Additional criteria, if necessary, can be included to the models. The results are intended to support environmental management and development planning of the costal municipalities surrounding the Patos Lagoon, some of them already suffering the socio-economic consequences of hydro-meteorological disasters. Figure 12 shows the flood risk model results for the years 1987 and 2000.

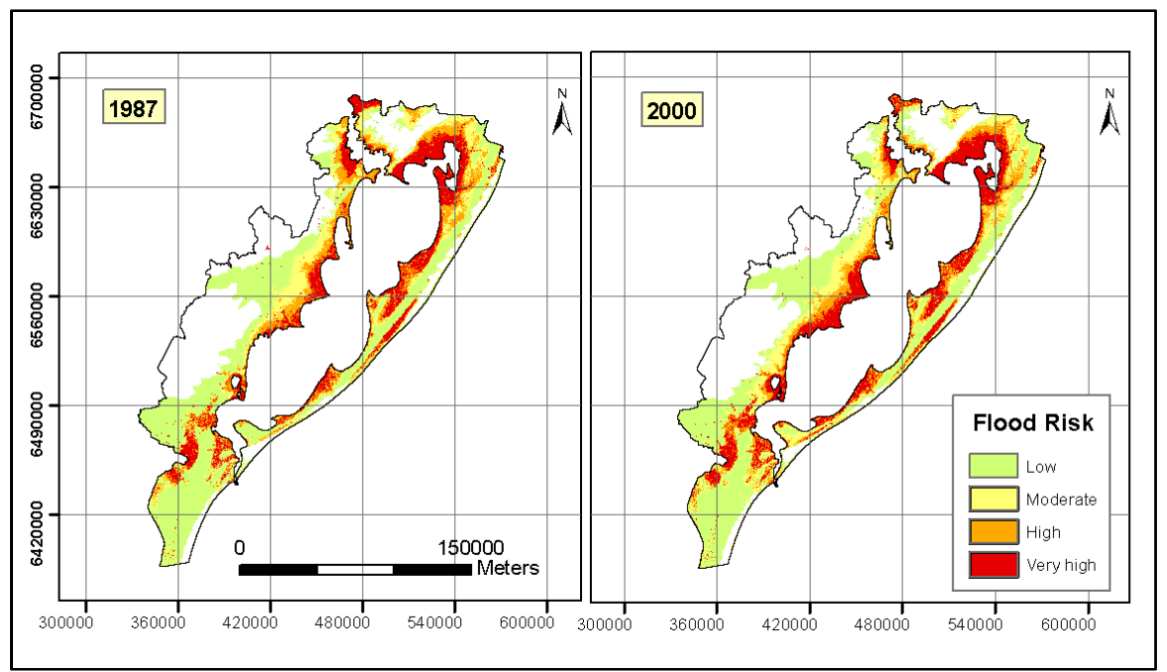

Figure 12. The flood risk images for the years 1987 and 2000. Universal Transverse Mercator, WGS-84. 
At least two major hydro-meteorological disasters were recorded in the west coast of Patos Lagoon in the last couple of years. In 2009, 8 people died, 1,200 left homeless, and a bridge was dragged due to an extreme rainfall and flood in Pelotas and Turuçu. In 2011, a similar event resulted in 8 more deaths and 20,000 homeless in São Lourenço do Sul. Half of the urban area was flooded. Two bridges were destroyed and many municipalities isolated. A close view of the model results shows how flood risk responded to land use changes in São Lourenço do Sul, the most impacted city by flood incidents (figure 13).

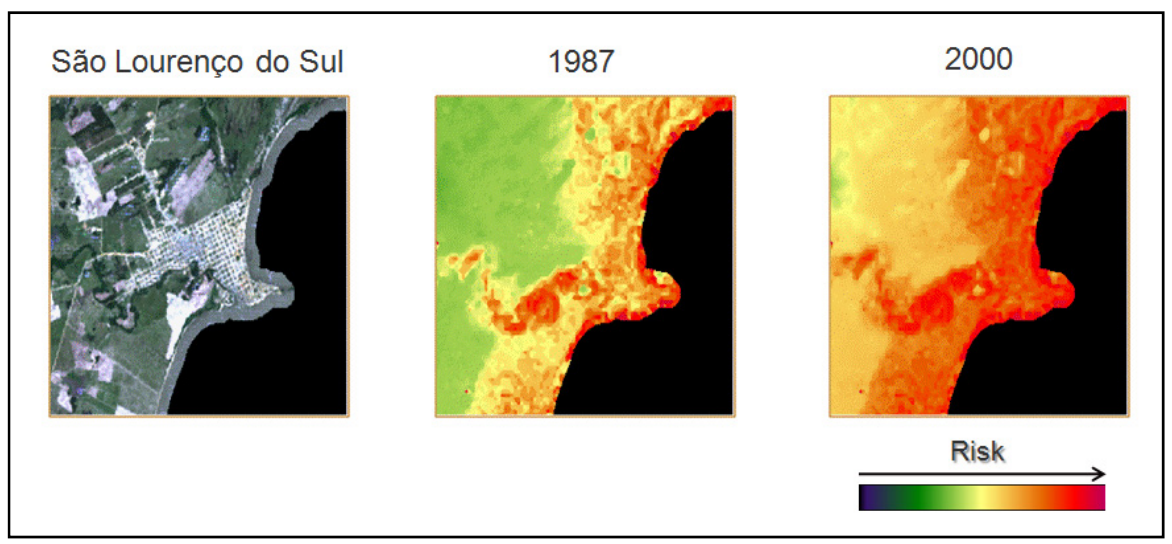

Figure 13. A close view of the flood risk model results for São Lourenço do Sul.
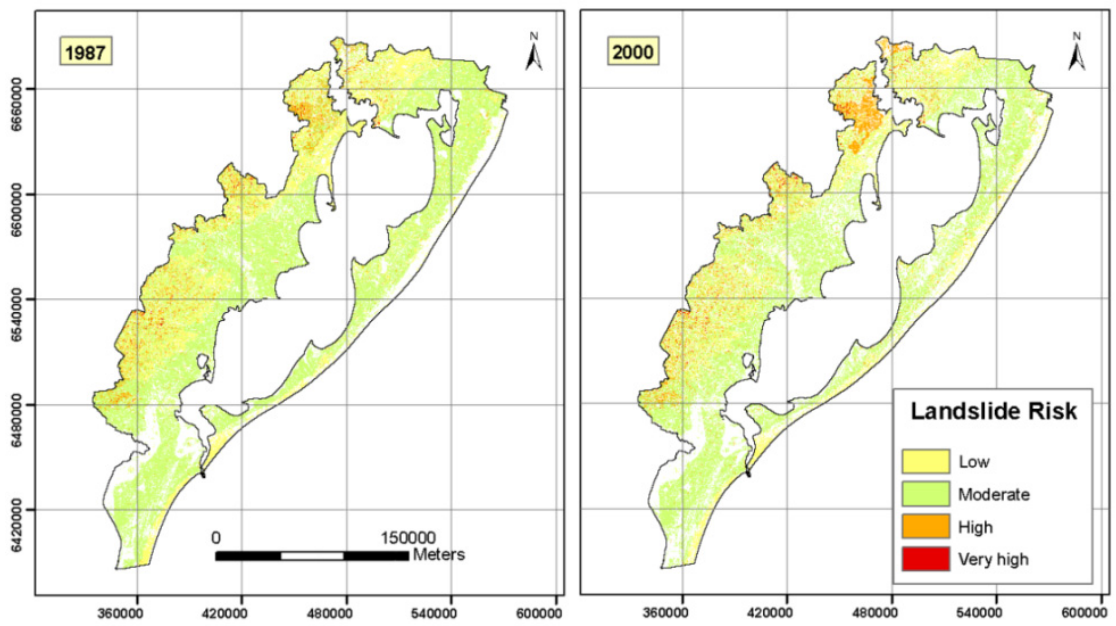

Figure 14. The landslide risk images for the years 1987 and 2000.

Landslides have not affected the region as much as flood, although local incidents have occurred in the last years. However, given the violence of some recent rainfall, combined with land use changes, we may infer about the imminent danger in many parts of the 
medium littoral. Rio de Janeiro already felt the consequences of this process, which resulted in serious disasters. Thus it is not a surprise if we start facing more severe landslides incidents in the Rio Grande do Sul as well. Figure 14 shows the GIS-based landslide risk results for the years 1987 and 2000.

\section{Strategies and recommendations to promote GIS as a knowledge translation tool in the realm of integrated coastal zone and ocean management in Southern Brazil}

Scientific understanding is crucial for a good ICM decision making (Cicin-Saint et. al., 1998). There is a necessity to establish a relationship between science and management and to incorporate scientific information into the management process. This is especially true in Brazil, where academics play a role beyond scientific production. They are indeed active actors in the coastal management process.

If we take a look at the five phases of the integrated coastal management process, we notice that in most of the cases we only took the first step: issue identification and assessment. It is true regarding integrated coastal management as a hole and also true when we consider the coastal management instruments alone. Even if we consider the I3Geo a successful initiative, we do not have evidences that it has supported the start of new cycles of management, where priorities and policies are adjusted to reflect experience and changing in social/environmental conditions. Besides, the platform works as an one-way tool, giving people access to cartographic information, but it does not promote the communication among sectors of society. The development of webGIS containing public participation tools is a way to overcome this limitation, promoting community empowerment through demand-driven, user-friendly and integrated applications of geoinformation.

The environmental management in Brazil is highly based on licensing. Thus, environmental licensing forces the information exchange between scientists, developers, and environmental agencies. On one hand, licensing is positive, driving research toward real social demands and promoting information interchange. On the other hand, change prediction and scenario generation studies are not required in the licensing process and, consequently, preventive planning is not encouraged. The inclusion of prospective studies in the policy instruments would enhance the efficiency of coastal management, allowing to focus actions on priority areas for development or conservation.

\section{Conclusion}

Academy is not responsible for defining the planning process, but it plays a major role in supporting it in Brazil, producing relevant information for the decision making process. Research results of some case studies were presented in this sense. Land changes, vital areas suppression, rural impoverishment, urban swelling, they are nothing else but governance failures. 
Once the Brazilian National Plan of Coastal Management instruments are spatial in nature, the GIS-based research works have already been helpful in improving the planning process in the Rio Grande do Sul coastal plain. Besides, the acquired knowledge in spatial modeling can be included into the existing instruments to promote their adaptation to the current pace and reach of human activities over the coastal zone.

Geological and geomorphologic mapping of coastal plain is presented here as the basis for land use planning. When coastal dynamic knowledge is applied to land use planning, environmental impacts of development are expected to be reduced.

Geotechnology is also important to urban development planning. The GIS-based model of urban sprawl of the Rio Grande city is an example of that, giving subsidies for management at local level.

Change detection and predictive modeling arise as a vital mean to support the adaption to the current environmental scenario of fast changes. Land use change and environmental risk models seem to bring significant advances in this sense.

A long journey must be undertaken before GIS products and recommendations produced by universities become actions. A new range of opportunities and challenges opens up, whether in the GIS-based environmental plans development and implementation or in further research in spatial modeling as a subside for risk management and coastal adaptation.

\section{Author details}

Tatiana S. da Silva, Maria Luiza Rosa and Flávia Farina

Federal University of Rio Grande do Sul, Institute of Geoscience, Brazil

\section{References}

Angulo, R.J. \& Lessa, G.C. 1997. The Brazilian sea-level curves: a critical review with emphasis on the curves from Paranaguá and Cananéia regions. Marine Geology, Vol.140, pp. 141-166.

Asmus, H.E., Garreta-Harkot, P.F., Tagliani, P.R.A. 1988. Geologia ambiental da região estuarina da Lagoa dos Patos, Brasil. Proceedings of VII Congresso Latino-Americano de Geologia. Belém. November 1988.

Cicin-Sain, B. Knecht, R.W., Kullenberg, G. 1998. Integrated coastal and ocean management: concepts and practices. Island Press. ISBN 1559636041. Delaware.

Corrêa, I.C.S. 1995. Les variations du niveau de la mer durant les derniers 17.500 ans BP: l'exemple de la plate-forme continentale du Rio Grande do Sul-Brésil. Marine Geology, Vol.130, pp. 163-178.

Dillenburg, S.R.; Roy, P.S.; Cowell, P.J. \& Tomazelli, L.J. 2000. Influence of antecedent topography on coastal evolution as tested by the shoreface translation-barrier model (STM). Journal Coastal Research, Vol.16, pp. 71-81. 
Dillenburg, S.R.; Tomazelli, L.J. \& Barboza E.G. 2004. Barrier evolution and placer formation at Bujuru southern Brazil. Marine Geology, Amsterdan, Vol.203, pp. 43-56.

Eastman, J. R. (1995). Idrisi for Windows User's Guide, Clark University, Worcester, USA.

Eastman, J. R.; Jin, W.; Kyem, P.A.K. \& Toledano, J. (1995). Raster procedures for multicriteria/multi-objective decisions. Photogrammetric Engineering and Remote Sensing, Vol.61, No.5 (May 1995), pp. 539-547, I SBN 0099111295.

Farina, F. C. (2003). Utilização de técnicas de geoprocessamento para seleção de áreas adequadas à expansão urbana: caso do município de Rio Grande-RS. UFRGS, Porto Alegre, Brasil.

Gómez, M. D. \& Barredo, J. I. C. (2005). Sistemas de Informacion Geográfica y evaluación multicriterio en la ordenación del territorio, RA-MA, ISBN 84-7897-673-6, Madrid, Spain.

Jablonski, S. \& Filet, M. 2008. Coastal management in Brazil - A political riddle. Ocean $\mathcal{E}$ Coastal Management. 51, pp. 536-543, ISSN 0964-5691.

Martin, L.; Suguio, K. \& Flexor, J.M. 1979. Le Quaternaire marin du littoral brésilien entre Cananéia (SP) et Barra de Guaratiba (RJ). Proceedings of International symposium of coastal evolution in the Quaternary, São Paulo, Brasil, pp. 296-331.

Rosa, M.L.C.C., 2010. Estratigrafia de Sequências: aplicação das ferramentas na alta frequência. Um ensaio na Planície Costeira do Rio Grande do Sul. Ph.D Qualifiyng. Instituto de Geociências. Universidade Federal do Rio Grande do Sul. Porto Alegre, Brasil. 67 p.

Silva, T.S., De Freitas, D., Tagliani, P.R.A., Farina, F.C., Ayup-Zouain, R.N. 2011. Land use change impact on coastal vulnerability: subsidies for risk management and coastal adaptation. Proceedings of CoastGIS 2011. Ostend. September 2011.

Silva, T.S. \& Tagliani, P.R.T. 2012. Environmental planning in the medium littoral of the Rio Grande do Sul coastal plain - Southern Brazil: elements for coastal management. Ocean $\mathcal{E}$ Coastal Management, Vol.59, pp. 20-30, ISSN 0964-5691.

Tagliani, C.R.A. 1997. Proposta para o Manejo Integrado da Exploração de Areia no Município Costeiro de Rio Grande - RS. Um Enfoque Sistêmico. UNISINOS, São Leopoldo, Brasil.

Tagliani, P.R.A., Landazuri, H., Reis, E.G., Tagliani, C.R., Asmus, M.L., Sánchez-Arcilla, A. 2003. Integrated coastal zone management in Patos Lagoon estuary: perspectives in context of developing country. Ocean E Coastal Management. 46, pp. 807-822, ISSN 09645691.

Toldo Jr., E.E.; Almeida, L.E.S.B.; Nicolodi, J.L. \& Martins, L.R.S. 2005. Retração e Progradação da Zona Costeira do Estado do Rio Grande do Sul. Gravel, Vol.3, pp. 31-38.

Tomazelli, L.J. \& Villwock, J.A. 1989. Processos erosivos na costa do Rio Grande do Sul, Brasil: evidências de uma provável tendência contemporânea de elevação do nível relativo do mar. Proceedings of Congresso da Associação Brasileira de Estudos do Quaternário 2th, p.16, Rio de Janeiro, Brasil.

Tomazelli, L.J. \& Villwock, J.A. 1992. Considerações Sobre o Ambiente Praial e a Deriva Litorânea de Sedimentos ao Longo do Litoral Norte do Rio Grande do Sul, Brasil. Revista Pesquisas, Porto Alegre, Vol.19, pp. 3-12.

Tomazelli, L.J. \& Villwock, J.A. 1996. Quaternary Geological Evolution of Rio Grande do Sul Coastal Plain, Southern Brazil. Anais da Academia Brasileira de Ciências, Vol.68, No.3, pp. 373-382. 
Travessas, F.A. 2003. Estratigrafia e evolução no Holoceno Superior da barreira costeira entre Tramandaí e Cidreira (RS). Instituto de Geociências, Universidade Federal do Rio Grande do Sul. Porto Alegre, Brasil. 